\title{
DELINEATION LITHUANIAN AGRICULTURAL LAND FOR AGRO-ECOLOGICAL SUITABILITY FOR FARMING USING SOIL AND TERRAIN CRITERIA
}

\author{
GINTARAS JARASIUNAS ${ }^{1 *}$, IRENA KINDERIENE, FERDO BAŠIĆ ${ }^{2}$ \\ ${ }^{1}$ Lithuanian Research Centre for Agriculture and Forestry, Instituto Av. 1, LT-58344 Akademija, Kedainiai distr., \\ Lithuania; e-mail: gintaras.jarasiunas@gmail.com \\ ${ }^{2}$ Croatian Academy of Science and Arts, Zrinski trg 11, 10000 Zagreb, Croatia
}

*Author for correspondence

\begin{abstract}
Jarasiunas G., Kinderiene I., Bašić F.: Delineation Lithuanian agricultural land for agro-ecological suitability for farming using soil and terrain criteria. Ekológia (Bratislava), Vol. 36, No. 1, p. 88-100, 2017

The aim of investigation is to analyse and classify the state of agricultural land affected by naturalbiophysical, that is, soil and terrain-slope, handicaps on its overall agro-ecological suitability for agricultural use. For the classification of land for suitability with respect to sustainable use and efficient protection, the following actual criteria were selected: soil texture, soil drainage and terrainslope. For identifying the relatively homogeneous areas, the Ward hierarchical cluster method was used. According to our estimates, Lithuanian agricultural land with unfavourable soil texture, poorly soil drainage and steep slopes covers an area of 33.59, 4.76 and $1.03 \%$ of total agricultural area, respectively. On the basis of functional classification of state of agro-ecological conditions of Lithuania, two orders of suitability (S-suitable, N-not suitable) and five land suitability classes were identified and delineated: S1 (highly suitable) included 10 district municipalities, S2 (moderately suitable) included 12 district municipalities, S3 (marginally suitable) included 15 district municipalities, N1 (currently not suitable) included 10 district municipalities and N2 (permanently not suitable) included 4 district municipalities. S3 occupies the largest $(29.80 \%)$ share of the Lithuanian territory and N2 the least (5.66\%). The land suitable for agriculture means with suitability classes S1, S2 and S3 was found on an area of 2,960,562 ha, which is $81.6 \%$ of the total land. In addition, soil texture was the most important factor causing differences in the classes of suitability. On the basis of natural limiting factors from an agronomic and eco-environmental perspective, the optimal sustainable development in agrosphere and a balanced-practical concept of land management and proper land use policy is presented. It is a reasonable base for agroecological regionalisation of Lithuania.
\end{abstract}

Key words: land suitability for agriculture, natural limiting factors, cluster analysis, suitability classes of agricultural land, land use policy.

\section{Introduction}

Spatial distribution of land use and cover types is influenced by both specific bio-physical characteristics, such as slope, climate and soil quality, as well as socio-economic factors. 
Natural constraints are limiting the overall land suitability for agricultural activity and cultivation practices (King et al., 1995; Van Diepen et al., 1991; Zabel et al., 2014). The FAO (1976) first developed a common framework for land evaluation in its present condition or after improvements. The process of land suitability classification is the appraisal and grouping of specific areas of land in terms of their suitability for defined uses (Deng et al., 2014). Land suitability characterised by comparing the quality of soil, climate and topography of land is united in the term agricultural region/subregion (Fontes et al., 2009; Bašić et al., 2007). These are the major determinants of the suitability of land for agricultural use (Fischer et al., 2002; Eliasson, 2007; Mayr et al., 1996). Land suitability classification system in this study referred to less-favoured areas (LFA) system in which specific indicators have been proposed as criterions to define intermediate LFAs in the European Union.

\section{Regionalisation of Lithuanian agriculture}

Mažvila et al. (2011) concluded that most important factors that determine the land regionalisation by suitability for agriculture are soil type, soil texture and chemical properties (soil $\mathrm{pH}$, nutrients $-\mathrm{P}_{2} \mathrm{O}_{5}$ and $\mathrm{K}_{2} \mathrm{O}$ supply). Finally, according to the long-term data from different physiographic and climatic areas, three clearly defined major agro-ecological regions (Western, Middle and Eastern) and seven sub-regions were conducted. In contrast, Gurklys et al. (2011) reported that focusing by soils, topography, amount and distribution of precipitation per year, two typical physiographic zones occur, which are represented by 15 soils - agricultural districts of Lithuania. Aleknavičius (2007) rated agricultural land in Eastern Lithuania as unsuited based on non-productive land and region have less favourable conditions for farming than other areas of the country. Bykoviene et al. (2014) estimated that in Lithuania, there are 23 municipal territories that have poor conditions for land use because of its rolling, hilly relief. Abalikštienė and Aleknavičius (2013), based on cartographic sources and recent statistical data, have identified that non-productive land is more abandoned and farming is less intensive than the regions prevailed by more productive land. Jarasiunas (2016) reported regionalisation of agricultural land for farming by steep slope criterion. The results showed that the terrain is a factor influencing land-use decisions. Slope steepness is essential for agricultural terrain classification to its suitability for general agricultural activity in Lithuania (Eidukevičienè, Vasiliauskienè, 2001). Results from the Global AEZ 2007 report (FAO/IIASA 2007) provided information that percentage occurrence of climate, soil and terrain constraints for rain-fed agriculture to all land is no constraints (1.7), slight constraints (74.4), moderate constraints (5.3) and severe soil constraints (14.6).

\section{Less-favoured areas (LFA) and biophysical constraints}

Since 1975, the designation of LFAs within the Common Agricultural Policy (CAP) recognises the specific features of areas presenting agro-ecological constraints (lack of water, climate, unfavourable soil and relief characteristics, short crop season and tendencies of depopulation), including mountainous or hilly features (MacDonald et al., 2000; Nori, 
Gemini, 2011). These areas have low agricultural potential because of limited and uncertain rainfall, poor soils, steep slopes or other biophysical constraints, as well as they may have higher agricultural potential but with limited access to infrastructure and markets, low population density or other socio-economic constraints (Van Keulen, 2006; Špulerová et al., 2016).

Since 2014, the areas with significant constraints are delimited based on agro-ecological conditions, especially natural properties that do not have the tendency to change over time. Limited factors such as biophysical indicators have been proposed as criteria to define intermediate LFAs in the European Union (Eliasson, 2007; Eliasson et al., 2010). The set of criteria is in line with an extension of FAO's agricultural 'Problem land' approach. A group of experts tasked by the Commission coordinated by the Commission's Joint Research Centre proposed eight common, that is, EU-wide, biophysical criteria for the new delineation of intermediate LFAs (Van Orshoven et al., 2008; Böttcher et al., 2009). The scientific background, definitions and proposed threshold values for these criteria are described by Van Orshoven et al. (2012).

According to the Lithuanian agro-environmental and climate conditions, five criteria are actual and important for the country, that is, low temperature, poor soil drainage, unfavourable soil texture, poor chemical properties and steep slope. Land use/cover and farming possibilities at different locations in Lithuania are mostly affected by different characteristics of the topography (elevation, slope, aspect) and soil (texture, nutrients status - supply, drainage conditions) (Eidukevičienè, Vasiliauskienè, 2001). The share of LFAs in Lithuania comprises $38.7 \%$ of all agricultural land. Agricultural land affected by specific natural constraints, which limits agricultural production and may increase the land abandonment, requires adaptive management with conservation strategies to ensure both productive and sustainable land management. This planning warrants adequate and accurate information on Lithuanian agricultural land territorial-scale differences in terms of natural constraints.

The aim of this investigation is to analyse the state of agricultural land affected by specific natural biophysical, that is, soil and terrain-slope, handicaps and to classify its agroecological suitability for agricultural use.

\section{Material and methods}

\section{Natural limitations (constraints) utilisation}

\footnotetext{
Administrative decision-level units (district municipalities) of Lithuania were classified by soil and terrain criteria. Soil and terrain criteria have been selected as a completely suitable and successfully applicable input for the classification of land for its overall suitability for use in agriculture. In this paper, suitability areas, called land suitability class, of Lithuanian agricultural land with natural limiting factors (soil physical properties, topography) were grouped with reference to three criteria:

- $\quad$ soil texture (topsoil texture class of sand and loamy sand or heavy clay or organic matter content in soil $(\geq 30 \%$ of at least $40 \mathrm{~cm})$ );

- $\quad$ soil drainage (gleyic colour pattern within $40 \mathrm{~cm}$ from the surface);

- $\quad$ slope $\left(\geq 15 \%\right.$ or $\left.7^{\circ}\right)$.

These criteria have been selected as a completely suitable and applicable input for the functional classification. For each criterion proposed by the panel of experts, the agronomic rationale, the definition, the scien-
} 
tific background, the assessment, the values for severe threshold and some references are provided in Technical Factsheet by Van Orshoven et al. (2012). Data used were calculated from state enterprise State Land Fund databases (Dirv_DR10LT, Mel_DR10LT, SRM_LT and KŽS_DB10LT). In total, the research included 51 district (rural) municipalities.

\section{Cluster analysis}

The soil and terrain criteria became a fundamental basis for distinguishing a homogeneous group of objects (district municipalities) in the studied population with the use of Ward's hierarchical clustering method, in which intra-group variation is taken into consideration. This leads to the creation of homogeneous clusters (Backhaus et al., 1996). Ward's method minimises the variance within clusters and tends to find clusters of relatively equal sizes. It is commonly used in territorial taxonomy (Roszkowska-Mądra et al., 2006; Dzienia et al., 2012; Taminskas et al., 2005, 2006). The most frequently selected metric, that is, the squared Euclidean distances (Sadowski, Czubak, 2013), was assumed as a measure of similarity between the objects. The dendrogram and the vertical icicle plot were used to determine the appropriate number of clusters that represent the structure of the responses. Mapping was performed with ArcGIS 10 software. Land suitability orders reflect the kinds of suitability; thus land suitability class reflects degrees of suitability within orders.

\section{Statistical analysis}

The statistical comparison amongst ascertained suitability classes by constraints was statistically estimated by Student $(\mathrm{t})$ test on a significance level of $p \leq 0.05$ (Bryman, Cramer, 1997). Student ( $\mathrm{t}$ ) test analysis was performed for all variables to identify statistically significant differences of variables that are major, key attributes contributing to the overall spatial diversity of the classes. Non-parametric Spearman correlation test was used to test the correlation amongst the land suitability classes (score values) and land productivity (point values). The z-score transformation was performed to standardise variables to the same scale. Statistical analyses were conducted in SPSS 11.5 software.

\section{Results}

\section{Classification and specification of agricultural land}

The execution of reckoning indicated that unfavourable soil texture, poor soil drainage and steep slope constraints covering an area of $33.59,4.76$ and $1.03 \%$, that is, $1,218,331$, 172,480 and 37, 425 ha, respectively, of total agricultural land in Lithuania. The dendrogram (data not shown) using Ward's method displayed five spatial homogeneous clusters of the district municipalities in accordance with natural soil and terrain constraints that limit generic agricultural activity in Lithuania. Land suitability class counts from 4 to 15 municipalities (Fig. 1).

The applied method of grouping objects allows for distinguishing agro-ecological suitability classes with different level of natural constraints of municipalities, whose statistical characteristics is shown in Table 1.

Class S1 (highly suitable) has included 10 municipalities (Jurbarkas, Šakiai, Kèdainiai, Joniškis, Pakruojis, Pasvalys, Mažeikiai, Akmenè, Šiauliai and Radviliškis) and has the lowest means of all studied criteria. In this class, the amount of unfavourable soil texture is lower by 37.7, 59.16, 68.4 and 77.52\% than in Class S2, Class S3, Class N1 and Class N2, respectively. This area contains relatively very low quantity of natural constraints. The percentage of common unfavourable land amounts to $19.13 \%$ of the total agricultural land, 


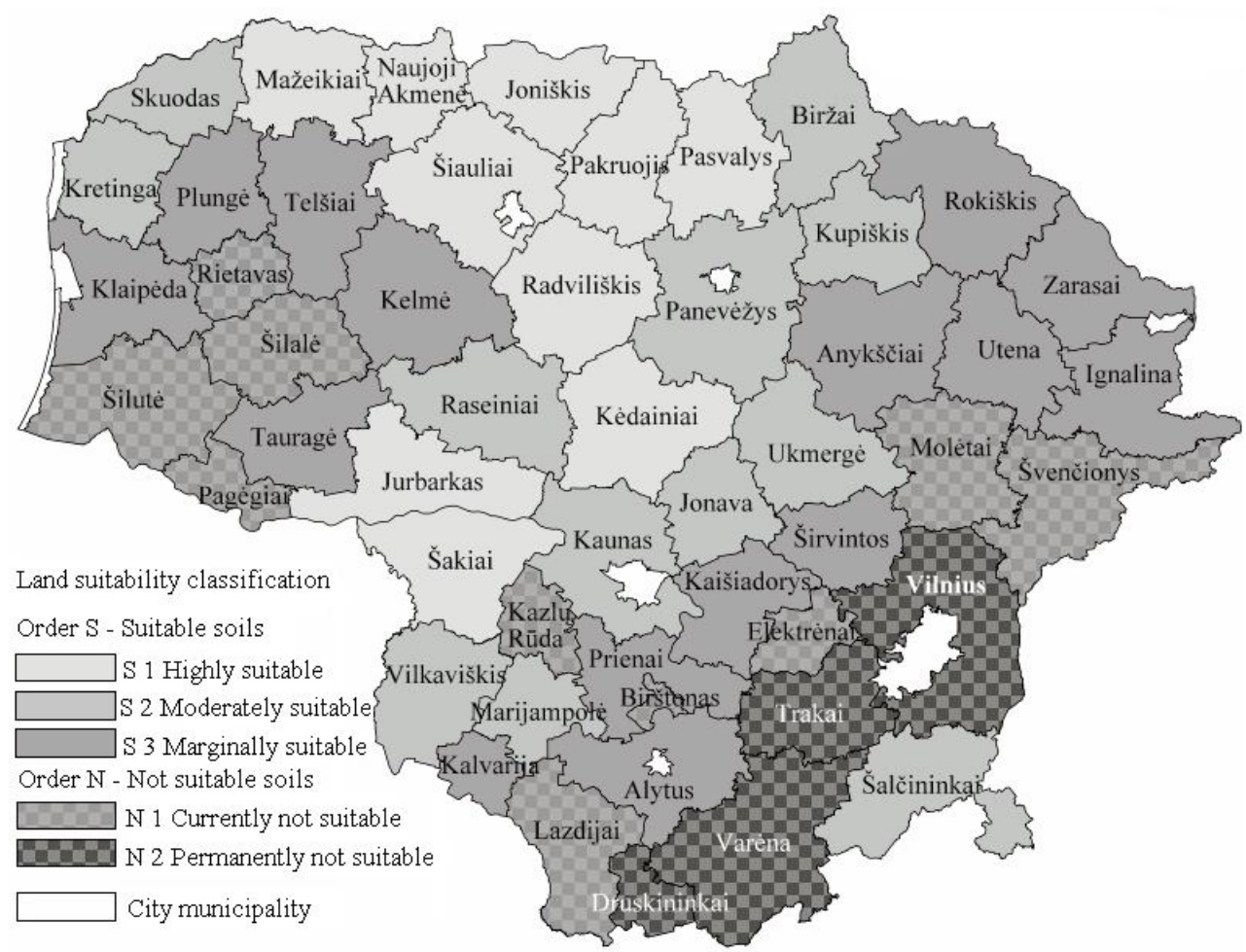

Fig. 1. Lithuanian agricultural land by the agro-ecological suitability for the generic agricultural use.

that is, lower by $35.57,59.98,68.81$ and $76.45 \%$ when compared with Class S2, Class S3, Class N1 and Class N2, accordingly. The counted share of agricultural land has amounted to $25.02 \%$ on all agricultural land of country. Additionally, the relevant highlight is the land productivity of the land under investigation, which reached up to 48.15 point, and it's higher by $13.08 \%$ than an average of Lithuanian agricultural land. Considering the presented results, this class has the most optimal and favourable natural agro-ecological and environmental conditions, that is, prevail fertile and well-drained soils, flat or gentle terrain, for agricultural development in the content of all formed suitability classes. Estimated amount of natural agro-environmental factors determinates favourable opportunities for a wide range of the agricultural activities or specific types of agriculture and farm economic performance.

Class S2 (moderately suitable) is interconnected with 12 municipalities (Skuodas, Kretinga, Biržai, Kupiškis, Panevėžys, Ukmergè, Jonava, Kaunas, Vilkaviškis, Marijampolè and Šalčininkai), which is rated due suitable conditions. From an agronomic perspective, with agricultural potential relatively similar to that in the Class S1, agricultural activities 
T a b l e 1. Statistical characteristics of natural limitations by suitability classes.

\begin{tabular}{|c|c|c|c|}
\hline \multirow[b]{2}{*}{ Statistics } & \multicolumn{3}{|c|}{ Natural limitations } \\
\hline & Unfavourable soil texture & Poor soil drainage & Steep slope \\
\hline \multicolumn{4}{|c|}{ Order S - suitable soils } \\
\hline \multicolumn{4}{|c|}{ Class S1, highly suitable $(\mathrm{n}=10)$} \\
\hline Mean $(\%) \pm$ SE & $16.21 \pm 1.09$ & $2.69 \pm 0.39$ & $0.28 \pm 0.05$ \\
\hline Min.-max. (\%) & $8.17-19.35$ & $1.27-4.65$ & $0.07-0.61$ \\
\hline CV (\%) & 21.18 & 46.27 & 57.78 \\
\hline $\mathrm{s}$ & 3.43 & 1.25 & 0.16 \\
\hline \multicolumn{4}{|c|}{ Class S2, moderately suitable $(n=12)$} \\
\hline Mean $(\%) \pm$ SE & $26.02 \pm 0.86$ & $3.13 \pm 0.34$ & $0.59 \pm 0.09$ \\
\hline Min.-max. (\%) & $22.39-31.73$ & $1.47-4.98$ & $0.13-1.06$ \\
\hline $\mathrm{CV}(\%)$ & 11.45 & 37.65 & 55.37 \\
\hline $\mathrm{s}$ & 2.98 & 1.18 & 0.33 \\
\hline \multicolumn{4}{|c|}{ Class S3, marginally suitable $(n=15)$} \\
\hline Mean $(\%) \pm$ SE & $39.69 \pm 0.79$ & $6.68 \pm 0.51$ & $1.84 \pm 0.28$ \\
\hline Min.-max. (\%) & $34.35-44.08$ & $3.67-10.08$ & $0.33-4.18$ \\
\hline $\mathrm{CV}(\%)$ & 7.69 & 29.57 & 58.15 \\
\hline $\mathrm{s}$ & 3.05 & 1.98 & 1.07 \\
\hline \multicolumn{4}{|c|}{ Order N - not suitable soils } \\
\hline \multicolumn{4}{|c|}{ Class N1, currently not suitable $(n=10)$} \\
\hline Mean $(\%) \pm$ SE & $51.29 \pm 1.80$ & $6.95 \pm 0.41$ & $1.57 \pm 0.49$ \\
\hline Min.-max. (\%) & $45.08-59.57$ & $5.18-8.87$ & $0.02-4.67$ \\
\hline CV (\%) & 11.09 & 18.61 & 98.97 \\
\hline $\mathrm{s}$ & 5.69 & 1.29 & 1.56 \\
\hline \multicolumn{4}{|c|}{ Class N2, permanently not suitable $(n=4)$} \\
\hline Mean $(\%) \pm$ SE & $72.12 \pm 2.93$ & $7.81 \pm 0.92$ & $1.91 \pm 0.73$ \\
\hline Min.-max. (\%) & $67.89-80.52$ & $6.49-10.45$ & $0.99-4.07$ \\
\hline $\mathrm{CV}(\%)$ & 8.12 & 23.44 & 76.15 \\
\hline $\mathrm{s}$ & 5.86 & 1.83 & 1.45 \\
\hline
\end{tabular}

are very diverse in this area ranging from the intensive to extensive farming, arable, mixed, livestock farming and horticulture. The measurements of agricultural land with natural constraints showed that $29.69 \%$ of land is handicapped (limited). The mean values of unfavourable soil by texture, poor soil drainage and steep slope are $26.02,3.13$ and $0.59 \%$, respectively. In this class, means of unfavourable soil texture, poor soil drainage and steep slope variables are 37.70, 14.06 and 52.54\% higher than those in Class S1. Followed by comparison with Class $\mathrm{N} 2$, the average of unfavourable soil texture, poor soil drainage and steep slope are lower by 63.92, 59.92 and $69.1 \%$, respectively. The estimated handicapped agricultural land in Class S2 was more by $35.57 \%$ than in the Class S1 but lower by $63.44 \%$ than in Class $\mathrm{N} 2$.

Class S3 (marginally suitable) consisted of 15 municipalities (Klaipèda, Plungè, Telšiai, Kelmè, Tauragè, Rokiškis, Zarasai, Ignalina, Utena, Anykščiai, Širvintos, Kaišiadorys, Pr- 


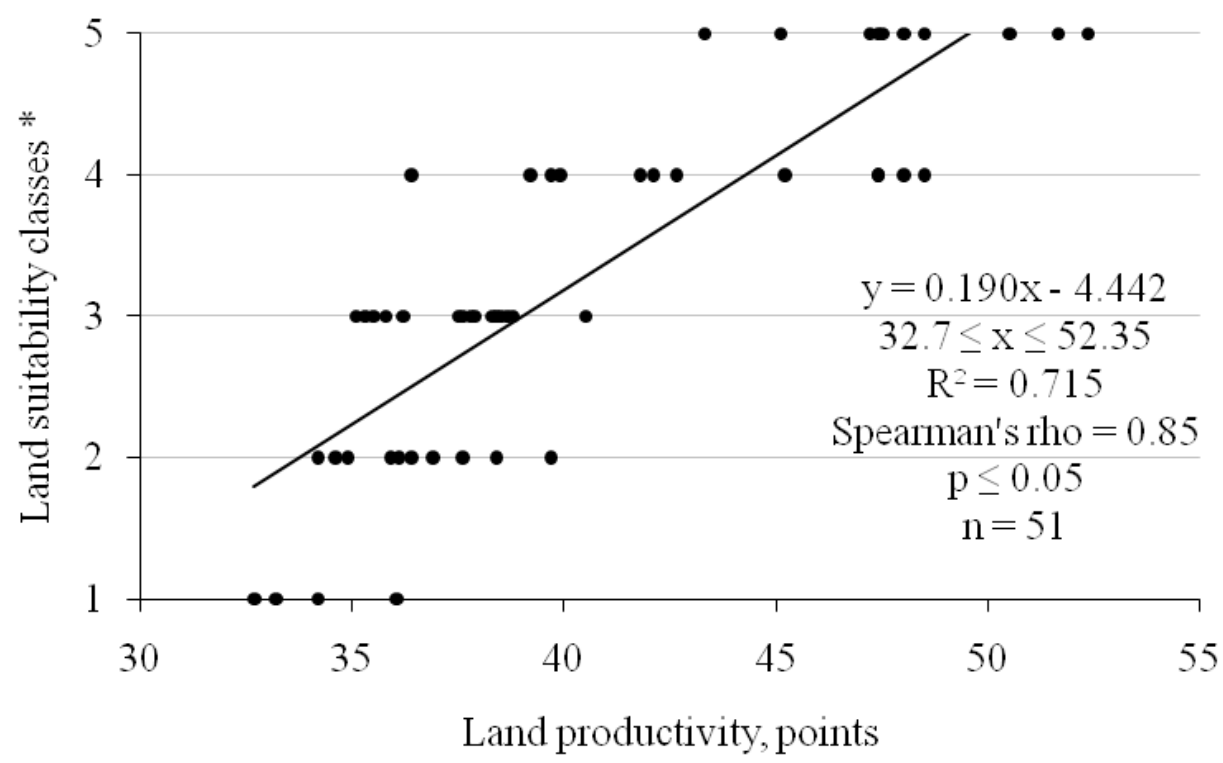

Fig. 2. Correlation of land (soil) productivity with land suitability class (rank scores), from the results of non-parametric Spearman's test.

*: Score values: 5 = Class S1; 4 = Class S2; 3 = Class S3; 2 = Class N1; 1 = Class N2.

ienai, Alytus and Kalvarija). The evaluated natural constraints have included $47.80 \%$ of all agricultural land of classes, that is, 59.52 and $37.89 \%$ more than that in the Class S1 and Class S2 and, however, by 22.07 and $41.45 \%$ lower when compared with the Class N1 and Class N2, respectively. The presented class is close to the Class N2, allowed for poor soil drainage, because therein mean value is higher by $3.88 \%$. Though, in Class S3, the determined participation of land under steep slope is higher by $14.67 \%$ in percentage than in Class N1, accordingly. In this analysed class, the conditions for generic agricultural activity are considered as marginally suitable.

Class N1 (currently not suitable) has integrated 10 municipalities (Rietavas, Šilalè, Šilutè, Pagègiai, Kazlų Rūda, Birštonas, Lazdijai, Elektrènai, Molètai and Švenčionys). The examined natural limitations for use in agriculture has formed 61.34\% (i.e. 282869 ha) of agricultural land on the whole area. The area formed 19.97, 19.00 and $18.02 \%$ of natural constrained agricultural land in Lithuania according to the analysed criteria. Comparing with Class N2 and Class S1, agricultural land in this class with natural constraints is lower by 24.49 and higher by $68.81 \%$, respectively. Natural constraints for use in agriculture have formed a part of whole natural constrained agricultural land by 20.33 and $7.80 \%$ of agricultural land of Lithuania. The area has been entitled as currently not suitable for the agricultural activity. 
T a b l e 2. Means comparison amongst land suitability classes by natural limitations.

\begin{tabular}{|l|c|c|c|c|c|c|}
\hline \multirow{2}{*}{ Compared classes } & \multicolumn{7}{|c|}{ Natural limitations } \\
\cline { 2 - 7 } & Unfavourable soil texture & \multicolumn{2}{|c|}{ Poor soil drainage } & \multicolumn{2}{c|}{ Steep slope } \\
\cline { 2 - 7 } & $\mathbf{t}_{\text {act. }}$ & $\mathbf{p}$ & $\mathbf{t}_{\text {act. }}$ & $\mathbf{p}$ & $\mathbf{t}_{\text {act. }}$ & $\mathbf{p}$ \\
\hline S1 and S2 & -10.447 & 0.000 & -1.256 & 0.230 & -3.457 & 0.004 \\
\hline S1 and S3 & -26.595 & 0.000 & -7.190 & 0.000 & -5.899 & 0.000 \\
\hline S1 and N1 & -43.465 & 0.000 & -19.724 & 0.000 & -9.011 & 0.000 \\
\hline S1 and N2 & -21.623 & 0.000 & -11.471 & 0.000 & -4.132 & 0.001 \\
\hline S2 and S3 & -11.613 & 0.000 & -5.639 & 0.000 & -4.259 & 0.001 \\
\hline S2 and N1 & -39.297 & 0.000 & -14.745 & 0.000 & -7.614 & 0.000 \\
\hline S2 and N2 & -17.474 & 0.000 & -7.956 & 0.000 & -3.211 & 0.006 \\
\hline S3 and N1 & -27.599 & 0.000 & -1.731 & 0.105 & -0.204 & 0.841 \\
\hline S3 and N2 & -7.858 & 0.000 & -0.465 & 0.649 & 0.701 & 0.495 \\
\hline N1 and N2 & 18.577 & 0.000 & 2.731 & 0.016 & 1.240 & 0.235 \\
\hline
\end{tabular}

Significant at $\mathrm{p} \leq 0.05$

Class N2 (permanently not suitable) has been characterised by the highest means of all studied natural constrained criteria. The above-mentioned area has unified four municipalities (Vilnius, Trakai, Varena and Druskininkai). This area formed 12.03\%, 9.45\% and $9.95 \%$ of all Lithuanian agricultural land under considered natural constrained criteria. The quantity of examined natural constraints is $81.23 \%$ of agricultural land area, that entailed, that agricultural land under favourable conditions takes a small part, i.e. $18.77 \%$ (38 520 ha). The unfavourable agricultural land of investigated class covers $4.59 \%$ of all Lithuanian agricultural land. The means of unfavourable soil texture, poor soil drainage and steep slope variables are $72.12,7.81$ and $1.91 \%$, respectively. It should be mentioned that average land productivity is considered as very low, that is, 34.04 point and, thus, less than that in the class under the highest suitable conditions (Class S1) and average in Lithuania by 29.30 and $18.66 \%$, respectively. This area was called as permanently not suitable because of the highest level of natural constraints with regards to all studied classes. In this as well as in land of Class N1, environmental agro-technical facilities with aid to protect soil from degradation should be used: shallow disking and non-arable cultivation, catch crops for green manure, mulch of chopped straw or hangover of stubbles during cold period, anti-erosive crop rotations.

Correlation-regression analysis showed that land (soil) productivity is highly $(\mathrm{r}=0.85$; $\left.\mathrm{R}^{2}=0.715 ; \mathrm{n}=51\right)$ and significantly $(\mathrm{p} \leq 0.05)$ correlated with land suitability class (Fig. 2$)$. Poor soils can influence land abandonment in marginal agricultural regions.

\section{Differences between suitability classes by constraints}

Each variable has their contribution to the grouping in concrete cluster. By using Student (t) test, it's possible to identify whether statistically significant differences exists amongst 
different suitability classes with similar variables. Conducting this type of statistical analyses enables estimation of variability between examined classes as well as indication of the most influencing variables. Then, unfavourable soil texture variable identified the most important pattern of the classes variation.

Results of the statistical analyses showed (Table 2) that primary variable having highest impact on land grouping should be ranked unfavourable soil texture criterion. This variable has showed 10 statistically significant differences amongst the classes events. Poor soil drainage and steep slope variables were placed under the secondary variables. These two above-mentioned variables have identified seven statistically significant differences amongst the class events. Therefore, it is possible to conclude that the impact of unfavourable soil texture criterion is most important cause for differences in groups of municipalities according to the suitability classes.

\section{Discussion}

Functional grouping of municipalities with the natural constrained agricultural land has shown that amongst the five classes of municipalities, the best agro-ecological and environmental conditions for agricultural development were in the Class S1, which includes 10 municipalities and the worst in the Class N2, which includes 4 municipalities. Of course, in agriculture, the main function of soil is a productive one, covered by the term "land resource potential' (Bašić et al., 2007). Land productivity in Lithuania is ranked by conventional points, which vary from 25 to over 50 . Depending on land productivity, the income from crop cultivation in different regions differs 3.5 times (calculated for 1 ha of agricultural land). Comparison of the income of farmers with favourable (fertile) and poor soils showed that they differ by 1.5 times (Povilaitis et al., 2015).

The accomplished research revealed that using clustering method by grouped municipalities as per natural soil and terrain constraints to the agricultural activity successfully indicated a significant diversity of conditions for the generic agricultural activity. Furthermore, agricultural land under natural constraints concentrates a large part of potential environmental values and services but, at the same time, is in the maximal risk of abandonment and/or intensification (Caballero, 2011; Kuliesis et al., 2011). According to Jarašiūnas and Kinderienè (2016), also Jarasiunas (2016), agricultural land suitability for farming in Lithuania is determined mostly by soil properties and topographical terrain features. The suitability of the territories for agricultural production is one of the most important criteria for the selection of measures necessary for the differentiation of the justification of the development of rural areas (Gurklys, Kvaraciejus, 2013; Kuyvenhoven, 2004). Comparatively, poor natural conditions for agriculture guarantee lower farm incomes and may force them to abandon farming (Rudow, 2014; Jarašiūnas, Kinderienè, 2015).

Soil texture is correlated with other important functional attributes such as water and nutrient storage capacity and thus has become a dominant criterion of all existing functional classification systems since soil began to be managed (Mueller et al., 2010; Hodgson et al., 1976). The results reported by Costantini and Lorenzetti (2013) revealed that amongst the biophysical criteria used to single out municipalities with predominantly 
less-favoured agricultural lands, soil constraints actually play the most important role. The most important driving force of soil degradation in Lithuania is unfavourable soils that have low productive value (Aleknavičius, 2007) and hilly areas at the risk of soil erosion (Jankauskas, 2012; Kinderienè et al., 2013).

The characteristic of agricultural land management differs from class to class depending on topography, fertility of soil, used in farming systems. Dominant soil types in Class S1 of agricultural land are Cambisols and Luvisols. Agricultural land with those soils is almost optimal for the cultivation of all arable crops, fruit and vegetables (Mažvila et al., 2011). The aids to improve soil quality by applying most effective eco-farming practices were investigated by Marcinkevičienè and Bogužas (2006). Classes N1 and N2 have high limitations for water and tillage erosion and risk of land abandonment because of predominant hilly relief. Conditions suitable for low-intensity farming systems are based on cattle breeding as dominant orientation. Soils under hilly topography status are not suitable for successful growing of crops by reason of steep slopes relating to intensive water erosion, which cause potential reduction of crop yield and land degradation processes (Kinderienè et al., 2013). On the $2-7^{\circ}$ slopes, applying grain-grass crop rotation are recommended, whilst on steeper than $7^{\circ}$ slopes, grass-grain crop rotation are recommended (Jankauskas et al., 2004; Kinderienè et al., 2013). Most of these measures proved effective in preventing erosion and increasing soil fertility and land productivity on the hilly terrain. In the Class $\mathrm{N} 1$ and Class N2, Albeluvisols and Arenosols prevail, whose productivity is approximately 40\% lower than Cambisols and Luvisols (Eidukevičienè, Vasiliauskienè, 2001).

Clustering of natural constraints and comparison of selected agricultural characteristics leads to the conclusion that these approaches have potential to be integrated into a national applicable assessment framework of the natural soil and terrain constraints, working on the municipality level in Lithuania. The ways and means in applied evaluation can be used as decision-making framework in order to decide best conservation measures and planning for rural development programmes. In LFAs, the retention of natural rural landscape and well-balanced farming activity practice are encouraged. This approach may serve as a reference base for ranking agricultural land potentials and as an operational tool for delineation of areas with different suitability types to farming development. Land grouping to suitability classes with regards to natural limitation for the generic agricultural activity in Lithuania showed rationale and applicable disparity in territorial units for the traditional and alternative land utilisation types.

\section{Conclusion}

Lithuanian agricultural land with unfavourable soil texture, poor soil drainage and steep slopes has accounted 33.59, 4.76 and $1.03 \%$, that is, 1, 218,331, 172,480 and 37,425 ha, respectively, of total agricultural area. Using cluster analysis, five homogeneous land suitability classes (areas) for generic agricultural activity in accordance with natural soil physical properties and topographic limitation were indicated.

Land suitability class count from 4 to 15 district municipalities. S3 occupies the largest area of Lithuanian territory (accounting for 29.80\%), and N2 the least (5.66\%). The land 
that is completely suitable and the most appropriate for agriculture activities was found to be $2,960,562$ ha with suitability classes S1, S2 and S3, which is $81.6 \%$ of the total agricultural land.

The natural constraint of unfavourable soil texture has identified the most important pattern of the land suitability classes variation. This variable has estimated 10 statistically significant differences amongst the studied classes events. The studied constraints of poor soil drainage and steep slope under secondary variables.

Data of soil properties used for land suitability classification with data on terrain-slopes is possible to use for agro-ecological valorisation of agrosphere of our state - agricultural regionalisation of Lithuania.

\section{References}

Abalikštienė, E. \& Aleknavičius P. (2013). Tendencies of agricultural land use in municipalities containing nonproductive land. Žemés Ūkio Mokslai, 20(3), 159-169. DOI:10.6001/zemesukiomokslai.v20i3.2739.

Aleknavičius, P. (2007). Land use problems in rural territories. Žemés Ūkio Mokslai, 14(1), 82-90.

Backhaus, K., Erichson, B., Plinke, W. \& Weiber R. (1996). Multivariate analysemethoden: eine anwendungsorientierte einführung. Berlin: Springer.

Bašić, F., Bogunović, M., Božić, M., Husnjak, S., Jurić, I., Kisić, I., Mesić, M., Mirošević, N., Romić, D. \& Žugec I. (2007). Regionalisation of Croatian agriculture. Agric. Conspec. Sci., 72(1), 27-38.

Böttcher, K., Eliasson, A., Jones, R.R., le Bas, C., Nachtergaele, F., Pistocchi, A., Ramos, F.F., Rossiter, D., Terres, J.M., Van Orshooven, J. \& Van Velthuizen H. (2009). Guidelines for application of common criteria to identify agricultural areas with natural handicaps. JRC Technical Note.

Bryman, A.E. \& Cramer D. (1997). Quantitative data analysis with SPSS for Windows: a guide for social scientists. Routledge.

Bykovienè, A., Pupka, D. \& Aleknavičius A. (2014). Analysis of agricultural land area registration and its changes in Lithuania. Žemés Ükio Mokslai, 21(4), 250-264. DOI:10.6001/zemesukiomokslai.v21i4.3028.

Caballero, R. (2011). The Common Agricultural Policy (CAP) towards 2020: How can fit farming in the marginal areas of the EU. Recent Researches in Energy, Environment, Entrepreneurship, Innovation, 13, 88-102.

Costantini, E.A.C. \& Lorenzetti R. (2013). Soil degradation processes in the Italian agricultural and forest ecosystems. Italian Journal of Agronomy, 8(28), 233-243. DOI:10.4081/ija.2013.e28.

Deng, F., Li, X., Wang, H., Zhang, M., Li, R. \& Li X. (2014). GIS-based assessment of land suitability for alfalfa cultivation: a case study in the dry continental steppes of northern China. Spanish Journal of Agricultural Research, 12(2), 364-375. DOI:10.5424/sjar/2014122-4672.

Dzienia, S., Pużyński, S. \& Wrzesińska E. (2012). Communes of less favoured areas in landscape parks of West Pomeranian Voivodeship. Acta Scientatiarum Polonorum, Agricultura, 11(1), 5-11.

Eidukevičienè, M. \& Vasiliauskienè V. (2001). Soils of Lithuania. Vilnius: Science and Arts of Lithuania.

Eliasson, A. (2007). Review of land evaluation methods for quantifying natural constraints to agriculture. Ispra: The Institute for Environment and Sustainability, Joint Research Centre.

Eliasson, Å., Terres, J.M. \& Bamps C. (2007). Common biophysical criteria for defining areas which are less favourable for agriculture in Europe. Ispra: The Institute for Environment and Sustainability, Joint Research Centre.

Eliasson, Å., Jones, R.R., Nachtergaele, F., Rossiter, D., Terres, J.M., Van Orshooven, J., Van Velthuizen, H., Böttcher, K., Haastrup, P. \& Le Bas, C. (2010). Common criteria for the redefinition of Intermediate Less Favoured Areas in the European Union. Environmental Science \& Policy, 13, 766-777. DOI:10.1016/j.envsci.2010.08.003.

FAO (1976). A framework for land evaluation. FAO. Soils Bulletin 32. Rome: FAO.

FAO/IIASA (2007). Global Agro-Ecological Zoning for 2007.

Fischer, G., Van Velthuizen, H., Shah, M. \& Nachtergaele F.O. (2002). Global agro-ecological assessment for agriculture in the $21^{\text {st }}$ century: methodology and results. Research report RR-02-02. Laxenburg: International Institute for Applied Systems Analysis.

Fontes, M.P.F., Fontes, R.M.O. \& Carneiro P.A.S. (2009). Land suitability, water balance and agricultural technol- 
ogy as a geographic-technological index to support regional planning and economic studies. Land Use Policy, 26, 589-598. DOI:10.1016/j.landusepol.2008.08.010.

Gurklys, V., Aleknavičius, P., Staugaitis, G. \& Kavoliutè F. (2011). Scientific approaches for the use of the land resources. Kaunas: Aleksandras Stulginskis University.

Gurklys, V. \& Kvaraciejus A. (2013). Expediency of the reconstruction of drainage systems. Žemés Ükio Mokslai, 20(3), 170-178. DOI:10.6001/zemesukiomokslai.v20i3.2740.

Hodgson, J.M., Hollis, J.M., Jones R.J.A. \& Palmer R.C. (1976). A comparison of field estimates and laboratory analyses of the silt and clay contents of some west Midland soils. Journal of Soil Science, 27, 411-419. DOI:10.1111/j.1365-2389.1976.tb02011.x.

Jankauskas, B. (2012). Soil erosion: case study, Lithuania. In Ch. Jakobsson (Ed.), Sustainable agriculture. Ecosystem health and sustainable agriculture (pp. 231-238). Uppsala: Baltic University Press.

Jankauskas, B., Jankauskiene, G. \& Fullen M.A. (2004). Erosion preventive crop rotations and water erosion rates on undulating slopes in Lithuania. Canadian Journal of Soil Science, 84(2), 177-186. DOI:10.4141/S03-029.

Jarašiūnas, G. \& Kinderienè I. (2015). Evaluation of generic farming conditions in Eastern Lithuania. Žemés Ūkio Mokslai, 22(2), 65-73. DOI:10.6001/zemesukiomokslai.v22i2.3111.

Jarasiunas, G. (2016). Assessment of the agricultural land under steep slope in Lithuania. Journal of Central European Agriculture, 17(1), 176-187. DOI:10.5513/JCEA01/17.1.1688.

Jarašiūnas, G. \& Kinderienè I. (2016). Impact of agro-environmental systems on soil erosion processes and soil properties on hilly landscape in Western Lithuania. Journal of Environmental Engineering and Landscape Management, 24(1), 60-69. DOI:10.3846/16486897.2015.1054289.

Kinderienė, I., Jarašiūnas, G. \& Karčauskienė D. (2013). Loss of plant nutrients (N, P, K) with soil loss and water runoff from hill slopes. Žemés Ükio Mokslai, 20(1), 10-19. DOI:10.6001/zemesukiomokslai.v20i1.2634.

King, D., Le Bas, C., Daroussin, J., Thomasson, A.J. \& Jones R.J.A. (1995). The EU map of soil water available for plants. In D. King, R.J.A. Jones \& A.J. Thomasson (Eds.), European land information systems for agroenvironmental monitoring (pp. 131-142). Luxembourg: Office for Official Publications of the European Communities.

Kuliesis, G., Salengaite, D. \& Kozlovskaja A. (2011). Land abandonment: problems and solutions. Vilnius: Lithuanian Agrarian Economics Institute.

Kuyvenhoven, A. (2004). Creating an enabling environment policy conditions for less-favored areas. Food Policy, 29, 407-429. DOI:10.1016/j.foodpol.2004.07.010.

MacDonald, D., Crabtree, J.R., Wiesinger, G., Dax, T., Stamou, N., Fleury, P., Gutierrez Lazpita, J. \& Gibon A. (2000). Agricultural abandonment in mountain areas of Europe: environmental consequences and policy response. J. Environ. Manag., 59(1), 47-69. DOI:10.1006/jema.1999.0335.

Marcinkevičienè, A. \& Bogužas V. (2006). The influence of catch crops and manure on soil bioactivity in sustainable and organic farming. Zemdirbyste-Agriculture, 93(4), 146-154.

Mayr, T.R., Rounsevell, M.D.A., Loveland, P.J. \& Simota C. (1996). Agro-climatic change and European soil suitability: regional modelling at monthly time-steps. International Agrophysics, 10, 155-170.

Mažvila, J., Staugaitis, G., Vaišvila, Z., Aleknavičius, P., Juozokas, A., Mockevičius, R. \& Lukšienė L. (2011). The productivity of Lithuanian's land. Kedainiai: Akademija.

Mueller, L., Schindler, U., Mirschel, W., Shepherd, T.G., Ball, B.C., Helming, K., Rogasik, J., Eulenstein, F. \& Wiggering H. (2010). Assessing the productivity function of soils. A review. Agronomy for Sustainable Development, 30, 601-614. DOI:10.1051/agro/2009057.

Nori, S. \& Gemini M. (2011). The Common Agricultural Policy vis-à-vis European pastoralists: principles and practices. Pastoralism: Research, Policy and Practice, 1(27), 1-8. DOI:10.1186/2041-7136-1-27.

Povilaitis, A., Lamsodis, R., Bastienė, N., Rudzianskaite, A., Misevičienė, S., Miseckaitė, O., Gužys, S., Baigys, G., Grybauskiene, V. \& Balevičius G. (2015). Agricultural drainage in Lithuania: a review of practices and environmental effects. Acta Agric. Scand. Sect. B - Soil Plant Sci., 65(suppl. 1), 14-29. DOI:10.1080/09064 710.2014.971050.

Roszkowska-Mądra, B., Gozdowski, D. \& Mądry W. (2006). Diversity of rural less-favoured areas in Podlasie province, Poland. Journal of Central European Agriculture, 7(4), 723-729.

Rudow, K. (2014). Less Favoured Area payments - impacts on the environment, a German perspective. Agricultural Economics-Czech, 60(6), 260-272.

Sadowski, A. \& Czubak W. (2013). The priorities of rural development in the EU countries in years 2007-2013. Agricultural Economics-Czech, 59(2), 58-73. 
Špulerová, J., Drábová, M. \& Lieskovský J. (2016). Traditional agricultural landscape and their management in less favoured areas in Slovakia. Ekológia (Bratislava), 35(1), 1-12. DOI:10.1515/eko-2016-0001.

Taminskas, J., Švedas, K. \& Konstantinova J. (2005). Fluctuation of the timescale of seasonal freeze in Lithuania. Geografijos Metrastis, 38(1), 18-28.

Taminskas, J., Švedas, K. \& Švedienè I. (2006). The changes in seasonally frozen ground depth in Lithuania. Annales Geographicae, 39(1), 15-24.

Van Diepen, C.A., Van Keulen, H., Wolf, J. \& Berkhout J.A.A. (1991). Land evaluation: from intuition to quantification. In B.A. Stewart (Ed.), Advances in Soil Science (pp. 139-204). New York: Springer.

Van Keulen, H. (2006). Heterogeneity and diversity in less-favoured areas. Agric. Syst., 88, 1-7. DOI:10.1016/j. agsy.2005.06.001.

Van Orshoven, J., Terres, J.M. \& Tóth T. (Eds) (2012). Updated common bio-physical criteria to define natural constraints for agriculture in Europe. Definition and scientific justification for the common criteria: technical factsheets. Luxembourg: Publications Office of the European Union. DOI:10.2788/91182.

Van Orshoven, J., Terres, J.M. \& Eliasson Å. (Eds). (2008). Common bio-physical criteria to define natural constraints for agriculture in Europe. Definition and scientific justification for the common criteria. Luxembourg: Office for Official Publications of the European Communities. DOI:10.2788/96289.

Zabel, F., Putzenlechner, B. \& Mauser W. (2014). Global agricultural land resources - a high resolution suitability evaluation and its perspectives until 2100 under climate change conditions. PLoS ONE, 9(9), e107522. DOI:10.1371/journal.pone.0107522. 